\title{
Fato e Análise
}

A seção Fato e Análise do número anterior da revista da ANDE focalizou o diretor de escola pública, concluindo que seu papel, enquanto educador, é "trabalhar para que ela (a escola) funcione, isto é, para que seus professores sejam competentes e “... consigam que seus alunos aprendam bem os conteúdos que eles se propõem a ensinar ... "

Vejam que ironia o fato que estamos apresentando neste número! Um professor secundário da rede pública, ao fazer com que seus alunos aprendessem bem o conteúdo que se propunha a ensinar, foi denunciado pela direção da escola e posteriormente cassado de sua função docente. Este professor não é outro se não Maurício Tragtenberg, que foi cassado em 64 e novamente em 68. Ele continua até hoje contribuindo sobremaneira para a Educação, através de suas obras, seus artigos na imprensa e sua atividade docente no $3^{\circ}$ grau. Sempre lutando ao lado do trabalhador, defende a melhoria da educação.

Assim como a sua escolha para ser paraninfo daquela turma, a publicação que hoje fazemos deste "relatório" representa o reconhecimento da importância de um educador que luta pela liberdade.

\section{Com toda a isenção de ânimo}

\section{Relatório}

Senhora Inspetora do Ensino Secundário e Normal

Atendendo a sua solicitação verbal, por ocasião de seu comparecimento a este Ginásio, no dia 19 do corrente, passamos a informar o seguinte:

I - Faz parte do corpo docente na qualidade de professor secundário de História Geral e do Brasil, o Sr. Maurício Tragtenberg, brasileiro, casado, licenciado pela Faculdade de Filosofia Ciências e Letras da Universidade de São Paulo, removido para este estabelecimento no Concurso de Remoção de 1961;

II - Nesta casa, em suas aulas desenvolvia doutrinação nos jovens, abusando da liberdade doutrinária de cátedra, captando desta forma a totalidade dos alunos para suas idéias. Por ocasião de um dos seminários houve até ridicularização de métodos pedagógicos de outros professores do estabelecimento;

I. Texto publicado originalmente na revista ANDE - Revista da Associação Nacional de Educação, ano 4, n.7, 1984, p.52-55. Reprodução autorizada. 


\section{( $\underline{c} \underline{6} \underline{\underline{I}} \underline{\underline{A}} \underline{1})$}

RELATORTO

Senbora joepetora ao Eneino Secundário e normal

A tenddeudo a sua solicita; to verbal, por ocaelato de eeu comparecimento. a este Ginásio, no dia 19 do corrente, pageamoo a lorormar a oegus to :

I- Paz parte co corpo docente na qualidade do profoesor encundário de História Geral e os Brasil, O Sr. Maurleso rragtenberg, braetleiro, casaco, Licenciado pela faculoado de plloeofia ciónolao

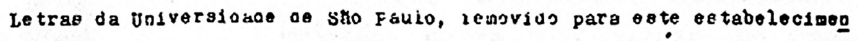

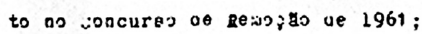

II- Neeta cuea, el euas aulas degenrolvia doutrinarăo noe jovens, abuéando a li dercade doutrinária de cátedra, captanas desta ra forma a totalidave oos aluoos p..ra suae ldélas. por scaglas de un dos ejexinários houve até ridicularizajus doe sétodor pedagócicos de outros professores do estauelecimento;

III- for scasialo da.eolenidade de entrega de certjficsdoe, a Dire; go se pronunciou aog quartaniletae, informando-og ve que nio afeen tirja a realizardo a o olenjaade cujo paraniofo era o profegeor Mauricjo Tragteniner e patroneses a profesoora Diva Damato, Latedrática de Tranลê.

Eroora o polegeor calearático ae matemática, Sr. M1l ton Demat to, houveses procuraco esta jiretoria no gotido de ooter eua sauéncia

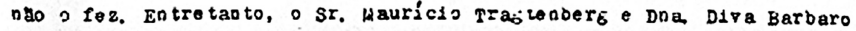
Damato, realizaram, a sua revella a solenioade do colajgo de grau que se caracterszou con o होino Naoxinal Eraeileiro;

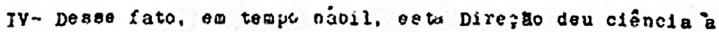
chefia do Eneino-secunóaxzo e Norgal, lormando o procesao núnero 1878/64-DE, wiraculosamente aesaparesias n. Departamento de Bducajto; $V$ - For veclaraizo veroal wo próprio profeger Naurício Tragteborg, feita a oala aje profeseores, conota.que fora detido. $\theta$ que eove traoalhos eotalo apreenaldos para posterior juloamed to;

YI- O selerido profezesr está af aetado dêste estabolecimento

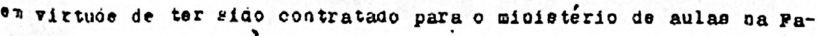
culdade de Pilosoria de sas josé do Rio preto.

O que ficoli al to, fal teito com tôa a leenpto de ândmo, eem

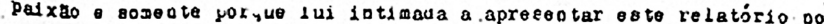
prazo de vinte e quatro horas, pela autoriage escolar a qued está o establecimento sucordioado e, por cuja girezalo, respondo.

D. C. B.

DIRETORA SUBSTITUTA 
III - Por ocasião da solenidade de entrega de certificados, a Direção se pronunciou aos quartanistas, informando-os de que não assentiria a realização da solenidade cujo paraninfo era o professor Maurício Tragtenberg e patronesse a professora Diva Barbaro Damato, catedrática de francês.

Embora o professor catedrático de matemática, Sr. Milton Damato, houvesse procurado esta Diretoria no sentido de obter sua anuência, não o fez. Entretanto, o Sr. Maurício Tragtenberg e Dna. Diva B. Damato, realizaram, a sua revelia a solenidade de colação de grau que se caracterizou com o Hino Nacional Brasileiro;

IV - Desse fato, em tempo hábil, esta Direção deu ciência à Chefia do Ensino Secundário e Normal, formando o processo número 1878/64-DE, miraculosamente desaparecido no Departamento de Educação;

V - Por declaração verbal do próprio professor Maurício Tragtenberg, feita na sala dos professores, consta que fora detido e que seus trabalhos estão apreendidos para posterior julgamento;

VI - O referido professor está afastado deste estabelecimento em virtude de ter sido contratado para o ministério de aulas na Faculdade de Filosofia de São José do Rio Preto.

O que acima ficou dito, foi feito com toda a isenção de ânimo, sem paixão e somente porque fui intimada a apresentar este relatório no prazo de vinte e quatro horas, pela autoridade escolar a quem está o estabelecimento subordinado e, por cuja Direção, respondo.

D. C. B.

DIRETORA SUBSTITUTA

\section{Sobre o papel do Diretor de Escola}

O fato que a Revista da ANDE apresenta neste número, para ser objeto de análise, emergiu por uma casualidade.

Necessitando de um documento comprobatório de sua experiência profissional em nível secundário, o Prof. Maurício Tragtenberg dirigiu-se ao Colégio do qual havia sido docente no início dos anos 60. E lá estava, em seu prontuário o relatório aqui estampado.

Assim, passados 20 anos, tem-se acesso ao registro de um dentre os vários fatos que colocaram Maurício Tragtenberg na mira da repressão desencadeada com o golpe militar de 64 . 
O documento estabelece um fato: sendo intimada a apresentar, no prazo de 24 horas, relatório sobre as atividades de um de seus subordinados, a diretora do Colégio produz um relato que incrimina o Prof. Maurício. Sim, este é o fato: o professor Maurício é acusado. E de que crime é ele acusado? De, em suas aulas, abusar da liberdade doutrinária de cátedra, desenvolvendo doutrinação aos jovens.

Ora, então, desenvolver atividade doutrinária é abusar da liberdade doutrinária? Até aí o que aparece de modo claro é o uso da referida liberdade. Onde estaria o abuso? Como ele se configuraria? Talvez o crime esteja na sequiência da acusação: desenvolvendo doutrinação aos jovens, o Prof. Maurício captava a totalidade dos alunos para suas idéias. A acusação indica, pois, que o referido professor era dotado de irresistível atração intelectual. Tanto assim que lograva atrair a totalidade dos alunos para suas idéias.

Mas ... não é isso exatamente o que se espera de um bom professor? Que ele seja intelectualmente convincente? Ou será que o bom professor é aquele que não dispõe de razóes lógicas e argumentos intelectuais capazes de convencer seus alunos?!

Por que se insurge a diretora contra a adesão dos alunos às idéias do professor Maurício? Haveria nelas algo tão perigoso a ponto do professor ser considerado réu do crime de difundí-las e - suprema culpa - obter êxito nessa difusão? Que idéias são essas? Sobre isso o relatório guarda absoluto e sepulcral silêncio.

$\mathrm{O}$ ato criminoso consistiria, pois, na transmissão pura e simples de idéias. Mais do que isso: tal ato era criminoso porque espantosamente eficaz, já que atingia, sem exceção, a totalidade dos alunos.

A constatação supra não deixa de ser sintomática. Pois não era exatamente sobre o obscurantismo que se procurava construir o regime que então se implantava? Em tais circunstâncias, era compreensível o temor às idéias. Buscavase não apenas calar o clamor da população como impedi-la de pensar. Se já era crime ter idéias próprias, crime maior seria difundi-las. Mas se a verdade é sempre revolucionária como pode o verdadeiro ensino deixar de ser revolucionário?

Como foi dito, o fato acima caracterizado veio à tona por mera casualidade. Quantos desses relatórios não estarão descansando nos prontuários dos professores? E quantos sequer por ali passaram, tendo ido diretamente para os arquivos dos órgãos de informação?

Até aqui analisamos o fato independentemente das intenções de quem o gerou. Objetivamente, a diretora exerceu o papel de delatora. Entretanto, não se pode avançar a interpretação de que ela tenha subjetivamente assumido tal papel, isto é, que ela tenha deliberada e intencionalmente se colocado nessa 
posição. Se assim fizéssemos estaríamos nos arvorando em juízes que, num ato revanchista, colocariam agora a diretora no banco dos réus.

Ao contrário, admitimos a hipótese de que a própria diretora tenha sido vítima dos mecanismos repressivos então desencadeados. $\mathrm{O}$ último parágrafo do relatório torna pelo menos plausível a referida hipótese. Vale a pena transcrevê-lo:

"O que acima ficou dito, foi feito com toda a isenção de ânimo, sem paixão e somente porque fui intimada a apresentar este relatório no prazo de vinte e quatro horas, pela autoridade escolar a que está o estabelecimento subordinado e, por cuja direção, respondo".

Acreditamos que não seja forçar demais o conteúdo do texto extrair do parágrafo supra a interpretação segundo a qual a diretora poderá ter agido movida por uma espécie de zelo funcional. Ciente de suas responsabilidades e de seu dever de prestar contas às autoridades superiores, introjetado o princípio do respeito incondicional à escala hierárquica considerada a razão de ser do funcionamento institucional, a nossa diretora provavelmente terá considerado que a sua "consciência profissional" não lhe deixava outra alternativa senão a apresentação do relatório nos termos em que o fez. Daí, sua referência à isenção de ânimo, ausência de paixão e à intimação da autoridade superior, como se estivesse sugerindo que, livre e espontaneamente, ela não tomaria tal iniciativa.

Nessa linha de interpretação parece evidente a deficiência de "consciência profissional" no que diz respeito à compreensão do verdadeiro papel do diretor de escola.

Dessa forma, julgamos ser pertinente estender ao fato que está sendo analisado as reflexões que desenvolvemos por ocasião da greve do magistério do Estado de São Paulo, em 1979, a propósito do papel do diretor de escola numa sociedade em crise: ${ }^{2}$

Dado o seu caráter de instituição, a escola possui uma organização que diferencia um conjunto de funções hierarquizadas, desempenhadas por diferentes atores que, através de objetivos específicos concorrem para a realização do objetivo central que é a razão de ser da instituição. O diretor apresenta-se, então, como o responsável máxi mo no âmbito da unidade escolar e seu papel poderia ser definido genericamente nos seguintes termos: garantir o bom funcionamento da escola. Obviamente esse "bom funcionamento" supōe a articulação das diferentes funçōes bem como a harmonização dos interesses dos diferentes atores no

2. SAVIANI, D. Educação: do senso comum à consciência filosófica. São Paulo, Ed. Autores Associados/ Cortez Ed. SP. 1980, pp. |89-191. 
interior da escola; de outro lado, considerando-se que a unidade escolar integra uma rede, o papel do diretor extrapola o âmbito da unidade articulando-a com as exigências do complexo escolar configurado no chamado "sistema de ensino".

Evidentemente a caracterização do papel do diretor supóe o entendimento do que significa "bom funcionamento" da escola; ou, noutros termos, supóe a resposta à pergunta: qual é o objetivo central que é a razão de ser da instituição escolar? Com efeito, garantir o "bom funcionamento" da escola implica garantir as condiçôes que viabilizem o atingimento de seu objetivo central.

Ora, só se compreende o significado da expressão "bom funcionamento" de uma instituição quando se compreende a natureza dessa mesma instituição. Assim, por exemplo, é próprio de uma empresa automobilística produzir automóveis; neste caso a direção da empresa estará cumprindo o seu papel de garantir o "bom funcionamento" da empresa, quando garante -as condiçôes que viabilizam em toda a sua plenitude o cumprimento do objetivo central que é a razão de ser da empresa: produzir automóveis. Pois bem; a partir dessa analogia (que não pode ser levada muito longe sob pena de se dissolver a especificidade dos diferentes tipos de instituição) percebe-se que a escola é uma instituição de natureza educativa. Ao diretor cabe, então, o papel de garantir o cumprimento da função educativa que é a razão de ser da escola. Nesse sentido, é preciso dizer que o diretor de escola é, antes de tudo, um educador; antes de ser um administrador ele é um educador. Mais do que isso: em termos típico-ideais, ele deveria ser o educador por excelência dado que, no âmbito da unidade escolar, lhe compete a responsabilidade máxima em relação à preservação do caráter educativo da instituição escolar. Esta é, em verdade, a condição precípua para que ele administre a escola mediante formas (atividades-meios) saturadas de conteúdo (atividades-fins).

Em termos concretos, entretanto, essa unidade de forma e conteúdo é uma unidade contraditória, estando o diretor continuamente sujeito ao risco de atrofiar o conteúdo educativo da escola (atividade-fins), hipertrofiando, em contrapartida, a forma (atividades-meios) chegando mesmo a operar uma inversão que tende a subordinar o fim aos meios. Diríamos, pois, que o diretor se vê concretamente diante de focos de pressão, de um lado (de cima e de fora), por parte do "sistema" que privilegia a forma sobre o conteúdo impondo um conjunto de exigências burocrático-administrativas; de outro lado (de baixo e de dentro), a pressão do conteúdo educativo que necessita ser desenvolvido no interior da escola sem o que ela se descaracteriza, se 
rotiniza e perde a razão de ser. Em termos ideais caberia ao diretor efetuar a mediação entre os dois focos de pressão, saturando de conteúdo as formas que decorrem das exigências da chamada "instância superior" (o sistema); sua ação se dirigiria, então, no sentido de subordinar e adequar as prescriçôes administrativas à finalidade educativa colimada no interior da escola. Na prática, poderíamos mesmo dizer que um diretor será tanto mais educador quanto maior o grau de autonomia que mantém em relação às exigências do "sistema", subordinando suas formas aos conteúdos educativos; e será tanto mais administrador quanto menor o grau de autonomia referido, o que o levará, em conseqüência, a se ater à rigidez das "normas superiores" mantendo-as esvaziadas do conteúdo que lhes daria sentido.

Em condiçôes sociais normais, a própria dinâmica da instituição gera mecanismos que garantem um mínimo de equilíbrio; delineiam-se, então, diferentes perfis de diretor segundo sua maior ou menor proximidade de um dos dois pólos de pressão. Entretanto, em condiçốes de crise, como aquela pela qual passa a sociedade brasileira, a contradição necessita ser resolvida e não apenas mantida.

A atual crise da sociedade brasileira é, fundamentalmente, uma crise de legitimidade. $\mathrm{O}$ poder legítimo é aquele que se funda no consentimento dos dirigidos, isto é, daqueles em relação aos quais o poder é exercido. No Brasil pós-64 assistiu-se à crescente hipertrofia da sociedade política (setor governamental) em relação à sociedade civil (conjunto das formas de organização dos diferentes setores da população da qual emana a legitimidade do poder exercido). Em conseqüência, a sociedade política que detém o monopólio do uso da força (mecanismos repressivos) perdeu o apoio da sociedade civil que opera na base do consenso (mecanismos persuasivos). Decorre daí o caráter ilegítimo do poder exercido pelo setor governamental.

No âmbito da organização educacional, essa situação de crise consubstanciada na contradição entre sociedade política e sociedade civil se manifesta através da contradição entre a "administração superior" e a atividade educativa que se desenvolve no interior das escolas. A crise decorre do fato de que as exigências da "administração superior" emergem como incompatíveis com a atividade educativa e vice-versa. Com isso rompe-se o equilíbrio e a contradição precisa ser resolvida. $\mathrm{O}$ "sistema" acredita resolver a contradição impondo pela força as suas exigências e com isso só faz aguçar a contradição, de vez que projeta sobre a escola, típico organismo da sociedade civil cujo modo de operar é a persuasão, formas típicas da sociedade política, lançando mão da repressão. A escola, por sua vez, busca resolver a contra- 
dição extraindo das exigências da atividade educativa novas formas de organização administrativa; com isso toma-se evidente e se desmascara a ilegitimidade das formas até então vigentes.

A situação acima descrita manifestou-se com clareza no fato objeto de análise. A autoridade superior, isto é, a Inspetora do Ensino Secundário e Normal, na prática, exigiu da diretora que se metamorfoseasse em delatora, função diametralmente oposta ao papel do diretor de escola. Tivesse a diretora uma sólida consciência profissional, compreendesse ela o verdadeiro papel do diretor de escola, e seu zelo funcional, em lugar de levá-la à consumação do fato analisado, ao contrário, tê-la-ia impedido de apresentar o relatório nos termos em que o apresentou. 